\title{
Multitemporal analysis of vegetated land cover changes related to tin mining activity in Bangka Regency using Landsat imagery
}

Ningsih Tassri, Projo Danoedoro, Prima Widayani

Ningsih Tassri, Projo Danoedoro, Prima Widayani, "Multitemporal analysis of vegetated land cover changes related to tin mining activity in Bangka Regency using Landsat imagery," Proc. SPIE 11311, Sixth Geoinformation Science Symposium, 1131104 (21 November 2019); doi: 10.1117/12.2548887

EDIE Event: Sixth Geoinformation Science Symposium, 2019, Yogyakarta, Indonesia 


\title{
Multitemporal Analysis of Vegetated Land Cover Changes Related to Tin Mining Activity in Bangka Regency Using Landsat Imagery
}

\author{
Ningsih Tassri*a,b, Projo Danoedoro ${ }^{\mathrm{c}}$, Prima Widayani ${ }^{\mathrm{d}}$ \\ aRemote Sensing MSc Program, Faculty of Geography Universitas Gadjah Mada Yogyakarta 55281; \\ ${ }^{b}$ Regional Environmental Office of Bangka Belitung Islands Province 33149 ; ${ }^{\mathrm{c}}$ Remote Sensing \\ Laboratory, Faculty of Geography Universitas Gadjah Mada, Yogyakarta $55281 ;$ d Department of \\ Geographic Information Science Remote Sensing Program Faculty of Geography Universitas Gadjah \\ Mada Yogyakarta 55281
}

\begin{abstract}
Tin mining is one of the main sectors of the national economy where the Bangka Regency is the largest tin producer in Indonesia. However, this sector cannot be separated from the pros and cons for a long time. In a way, this sector can increase both national and regional income but on the other side, the adverse effects of it can threaten the survival of humans and the environment. Open tin mining activity has converted previously vegetated land cover become the nonvegetated land cover. Furthermore, the land cover changes to the mining area have a major impact on global warming which has become an international issue in the past few decades. This research aims to map and measuring land cover changes especially from vegetated to non-vegetated land cover related to tin mining activity in Bangka Regency. This research using multi temporal Landsat imagery data acquisition in the year 2004 (Landsat 5 TM) and 2017 (Landsat 8 OLI) through digital image processing using Maximum Likelihood Classifier method. Previously, the image as a classification input through relative radiometric normalization. The result shows that tin mining activity in Bangka regency for thirteen years causes an area reduction in vegetated land cover. These results are expected to be an important input in policymaking for local governments to support the action plan which leads to mitigation of climate change.
\end{abstract}

Keywords: remote sensing, multi temporal analysis, land cover changes, tin mining, maximum likelihood

\section{INTRODUCTION}

Tin is one of the important minerals. The increasing need for tin especially in the electronics industry in the early $2000 \mathrm{~s}$ made the mining industry strive to supply this mineral ${ }^{[1]}$. In Indonesia, one of the provinces that rely on tin mining is the dominant sector, namely the Bangka Belitung Islands Province. Tin reserves in this region are in the path of The Indonesian Tin Belt, which stretches for 800 kilometer ${ }^{[2]}$. The history of tin mining in this archipelago began in the 18th century until finally, mining activities began to develop rapidly during the Dutch colonial era until the present ${ }^{[3]}$.

Tin mining activities convert a lot of previously vegetated land into non-vegetated land. With the increasing number of changes in land cover has caused serious pressure on the environment in the Bangka Belitung Islands. Former tin mining, especially unconventional tin, is generally left open without reclamation, causing water-filled basins in the rainy season ${ }^{[4]}$. Another impact is related to the release of radioactive minerals following a lead to the environment to land degradation ${ }^{5}$. Bangka Regency is one of the regions that contain a large number of tin minerals so that here there is a lot of mining activity going on and illegal. The anticlimax of local government policies at that time in improving the economic welfare of the community became a contradiction at this time if seen from massive environmental damage caused by mining activities $^{[6]}$.

Deforestation and forest degradation in mining areas are generally located in areas with very low accessibility. Related to this, the activity of monitoring changes in land cover accurately and periodically is an important aspect of environmental monitoring ${ }^{[7]}$. Remote sensing technology is the right method to be applied in this study because some of its advantages are a synoptic overview and can be analyzed in time series ${ }^{[8]}$.

*ningsihtassri10@gmail.com; phone 085710826150

Sixth Geoinformation Science Symposium, edited by Sandy Budi Wibowo, Andi B. Rimba

Stuart Phinn, Ammar A. Aziz, Proc. of SPIE, Vol. 11311, 1131104 · ( 2019 SPIE

CCC code: $0277-786 \mathrm{X} / 19 / \$ 21 \cdot$ doi: $10.1117 / 12.2548887$

Proc. of SPIE Vol. $113111131104-1$ 
The research related to land changes due to widespread tin mining in the previous Bangka Regency has done using Landsat image recording time in 2004, 2009 and 2014 using visual interpretation technique and balance spatial analysis. The results show that in the period 2004 to 2009 the tin mining area increased by $4370.20 \mathrm{Ha}$ where the annual growth rate was 874.04 Ha while in the period 2009 to 2014 it increased by $2421.6 \mathrm{Ha}$ with an average growth rate of $484.21 \mathrm{Ha}^{[9]}$. In addition to visual interpretation there also known digital interpretation techniques. This study aims to find out and spatially examine the of changes in vegetated land cover related to tin mining activities in the Bangka Regency region during the period 2004 to 2017 through digital image interpretation techniques.

\section{METHODOLOGY}

\subsection{Image Pre-processing}

This stage is the preparation stage before the image can be used, namely by making several corrections to the image, making composite images, and cropping the study area on the image with administrative boundaries using ENVI software version 5.1. In this study Landsat imagery used is at the L1TP correction level or the terrain precision standard, which means it has been corrected geometrically using ground control point and DEM altitude data to correct geometric errors due to the earth's surface relief factor. However, to increase confidence in the precision of geometric corrections that have been made, the corrected image is plotted with RBI map as basic geospatial data with the same or greater scale than the data to be created. Radiometric correction is then carried out where the main objective is to improve image quality while improving the pixel values of an object that does not match the actual reflection value ${ }^{[10]}$. Furthermore, the image composite used is a combination of 742 on Landsat 5 TM and a combination of 752 bands on Landsat 8 OLI. The use of this channel combination is one of them based on previous research where the reflection value of open mining objects is high, especially in SWIR and NIR bands so that it is easy to identify and differentiate from another land cover during the process of taking the training area to carry out multispectral classification ${ }^{[2]}$.

\subsection{Multi-temporal Image Classification}

Land cover data is extracted from remote sensing images through digital interpretation techniques by applying a supervised classification system. This research using maximum likelihood classification method. This method is the most commonly used method in the classification of land cover by considering the opportunity factor of one pixel to be categorized in a certain class. The minimum number of pixels for the training area in this study is at least 100 pixels for each land cover class. In a multispectral classification the samples taken were attempted homogeneous. Through the appearance of a good composite image, the homogeneity of objects is reflected by uniform colors. The land cover classification refers to SNI 7645.1: 2014 concerning Classification of Land Cover - Part 1: Small and Medium Scale with the land cover class as follows: Built-up Area, Opencast Mining Area, Water Bodies, Highland Forest, Lowland Forest, Swamp, Shrubs, Garden and Mixed Plants, Oil Palm Hardwood Plantation, Rubber Hardwood Plantation, Herbs and Grass, and the last land cover class is Mangrove Forest.

There are some considerations for using this method based on the breadth of the study area and the local knowledge that the author has regarding the characteristics of the study area, making it easier to interpret objects. The Maximum Likelihood algorithm is seen as a method that can provide the best results in land cover/ land use classification ${ }^{[11]}$. However, to obtain accurate classification results, it is necessary to select training areas that are truly homogeneous in quantities such that they can represent each land cover class.

\subsection{Accuracy Assessment}

Accuracy assessment is important to show the degree of truth from the classification results ${ }^{[12] .}$ Testing classification accuracy is done by stacking reference data and digital classification data ${ }^{[13,14]}$. The accuracy of the mapping is done by making a contingency matrix or confusion matrix to calculate Overall Accuracy, User Accuracy, Producer Accuracy and Kappa Index. In mathematics, these accuracy calculation is stated by the following formula:

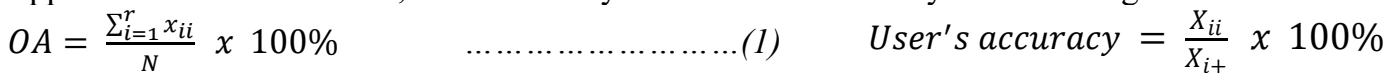

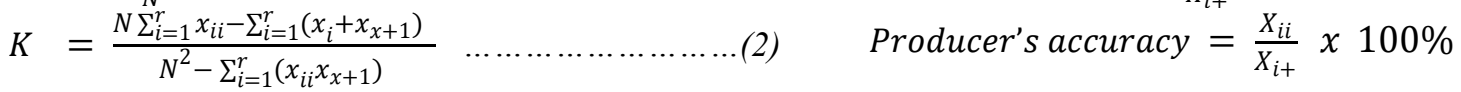




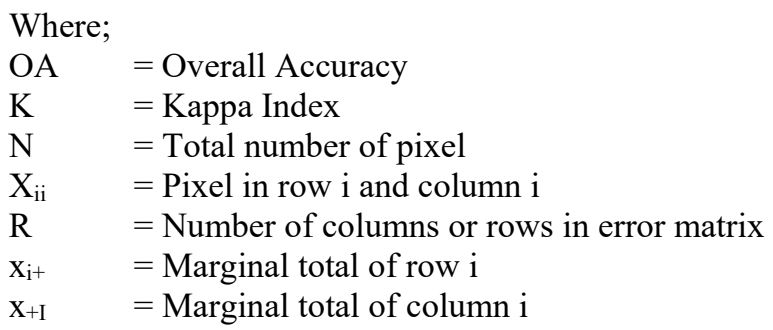

\subsection{Spatial Analysis of Vegetated Land Cover Changes to Opencast Mining Areas}

The results of digital interpretation of Landsat 5 TM images in 2004 and Landsat 8 OLI in 2017 in the form of land cover classifications were subsequently converted into vector form and then spatial analysis was performed, namely overlaying techniques between 2 maps of multi-time land cover classification using ArcGIS software version 10.2.2. The area of each land cover and its changes are displayed in the form of a land cover change matrix. Furthermore, the results of the overlay technique will show spatially while measuring the magnitude of changes in land cover previously vegetated to nonvegetated land related to tin mining activities.

\section{DATA}

\subsection{Study Area}

This research is located in parts of Bangka Regency which covers 6 sub-districts, namely Belinyu, Riau Silip, Merawang, Bakam, Pemali, and Sungailiat. Astronomically, the research location is between $131^{\circ} 32^{\prime} 72^{\prime \prime}$ LS to $2^{\circ} 3^{\prime} 76^{\prime \prime}$ LS and $105^{\circ} 40^{\prime} 51.59^{\prime \prime}$ BT to $106^{\circ} 10^{\prime} 23.03^{\prime \prime}$ BT. Geographically, the research location is bordered by Karimata Strait in the north and east side, then Pangkalpinang City and Central Bangka Regency in the south and bordered by West Bangka Regency in the west.

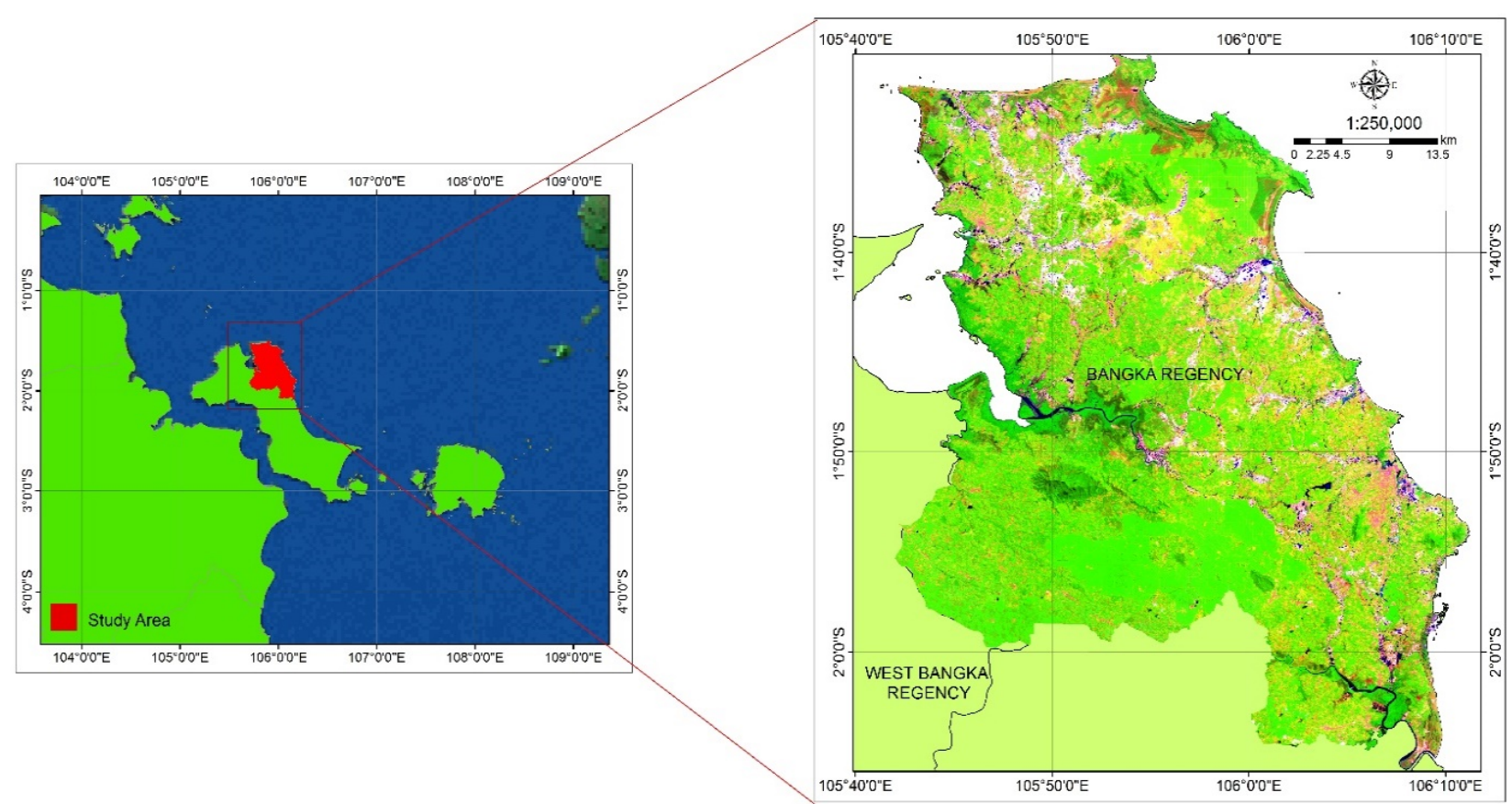

Figure 1. Research Location by using Landsat 8 OLI composite RGB 752 


\subsection{Data}

The satellite imagery that used in this research included of two cloud-free Landsat scenes path/row 123/61 which has a spatial resolution of $30 \mathrm{~m}$ : (1) Landsat 5 Thematic Mapper (TM) with the acquisition date of August 7, 2004, and (2) Landsat 8 Operational Land Imager (OLI) with the acquisition date on July 26, 2017. From the previous study, Landsat 5 TM and Landsat 8 OLI images in the study of land cover in the mining area resulted in satisfactory classification accuracy [11]. Both of these image data are downloaded through the https://earthexplorer.usgs.gov/ page with an image level of 1TP (corrected terrain). All data were projected to UTM 48S Datum WGS84. The reference data in this research is taken from the ground survey. The sample collected in the field consisted of a model builder sample and an independent sample to test the accuracy of image interpretation. Then, the other data that used is a 1: 50,000 digital Indonesian scale (RBI) map that is downloaded from the http://tanahair.indonesia.go.id/portal-web page as material for geometry correction and administratively limiting the location of the study.

\section{RESULTS}

\subsection{Land Cover Classification}

The image processing stage which includes correction of the image is important before the process of land cover classification. In this study, geometric corrections in both images apply $2^{\text {nd }}$ order polynomial equations with each of the 12 ground control points and root mean square error (RMSE) values in Landsat 5 TM and Landsat 8 OLI images respectively 0.4956 and 0.5366 so that the geometric accuracy obtained has met the requirements RMSE $<1$. At the time of the geometric correction process is also carried out the process of resampling the pixel value of the image with the nearest neighbor method that is placing the value of the nearest neighboring pixel to fill the shifted pixels so that the resulting pixel value is not much different from the image pixel value before the geometric correction process. Analysis of multi-temporal satellite images in this study reduced spectral information so that the atmospheric correction model carried out in this study was a relative atmospheric correction.

Combination band of 741 Landsat $5 \mathrm{TM}$ as well as the combination of 752 on Landsat 8 OLI, the tin mining area as the main study object was identified by the appearance of bright white to pink color with an elongated pattern. For basin areas, the remaining tin mining that has been filled with water is shown in blue color.

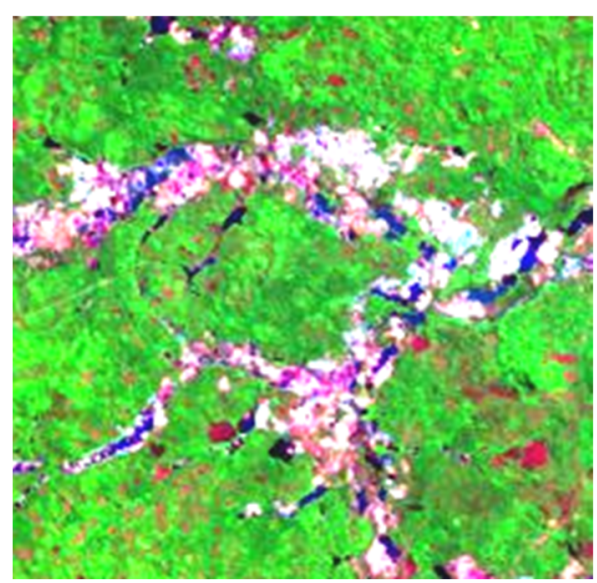

Figure 2. Landsat 5 TM using composite RBG 741

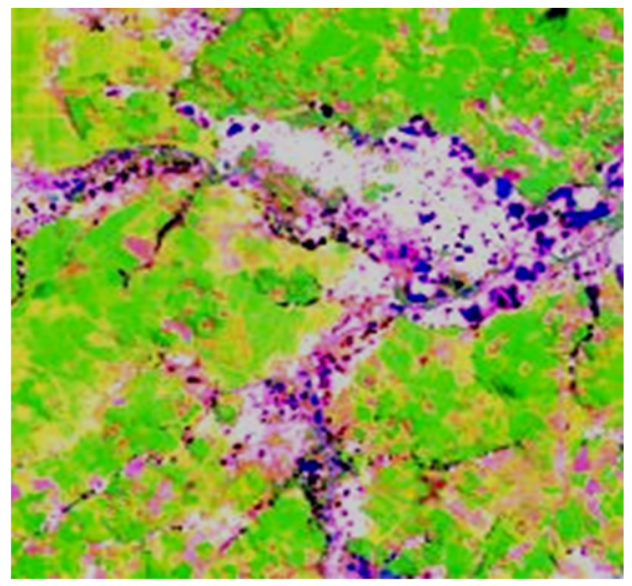

Figure 3. Landsat 8 OLI using composite RBG 752

The ground checking in the field to collecting samples for reinterpretation and testing the accuracy assessment of image interpretation then gives the actual conditions of opencast tin mining land cover areas which shown by the following figures below; 


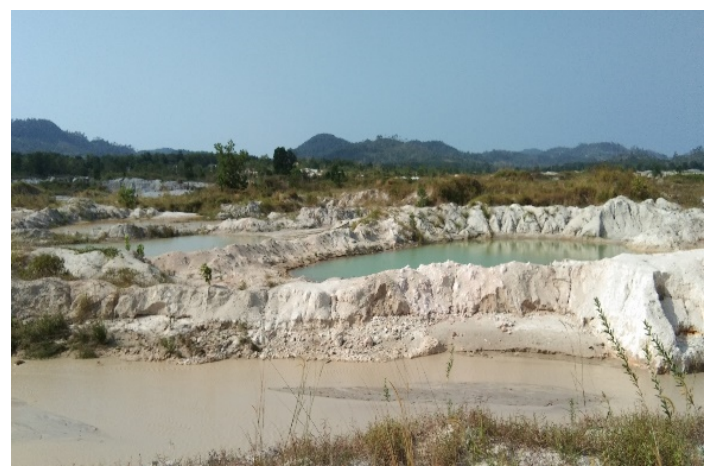

Figure 4. Ground survey sample located in Belinyu District

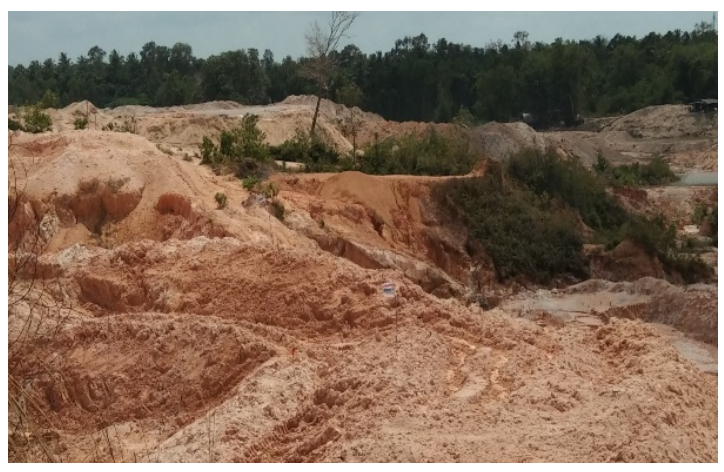

Figure 5. Ground survey sample located in Pemali District

The results of the supervised classification using the maximum likelihood algorithm in 2004 and 2017 Landsat image show the spatial distribution of land cover as shown in Figure 4 and Figure 5 below:
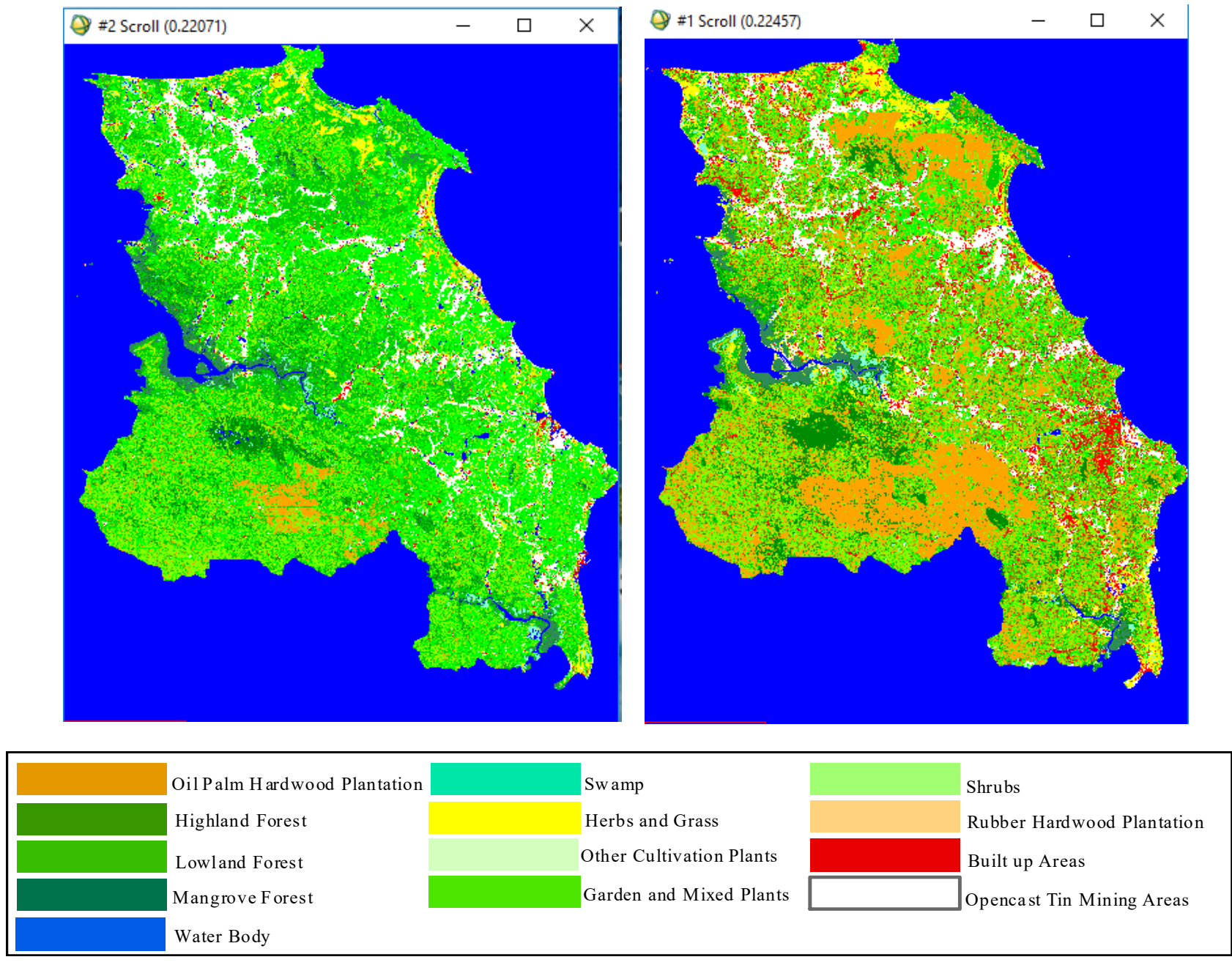

Figure 6. Classification Result by Landsat $5 \mathrm{TM}$

Figure 7. Classification Result by Landsat 8 OLI 


\subsection{Spatial Changes of Vegetated Land Cover become Opencast Tin Mining Areas.}

From the results of data analysis using geographic information systems, it is known that the total area of land cover in the study location is $2.059,17 \mathrm{~km}^{2}$. The dominant land cover class at the research location in the year 2004 is garden and mixed plants with an area of $526,68 \mathrm{~km}^{2}$ while in the year 2017, oil palm hardwood plantation become increased significantly to reach $458,70 \mathrm{~km}^{2}$. The detailed information of land cover classes in the year 2004 and 2017 is shown on table 1 and figure 8 below;

Table 1. Information of land cover changes in 2004 and 2017

\begin{tabular}{|c|c|c|c|c|}
\hline \multirow[b]{2}{*}{ Land Cover } & \multicolumn{4}{|c|}{ Extent of the Year } \\
\hline & \multicolumn{2}{|c|}{2004} & \multicolumn{2}{|c|}{2017} \\
\hline Low land forest & 527,82 & 25,63 & 154,05 & 7,48 \\
\hline High land forest & 266,80 & 12,96 & 222,23 & 10,79 \\
\hline Mangrove forest & 61,63 & 2,99 & 40,79 & 1,98 \\
\hline Swamp & 32,96 & 1,60 & 23,13 & 1,12 \\
\hline Gardens and mixed plants & 526,68 & 25,58 & 301,60 & 14,64 \\
\hline Built up area & 30,46 & 1,47 & 146,46 & 7,11 \\
\hline Rubber Hardwood Plantation & 113,54 & 5,51 & 274,74 & 13,43 \\
\hline Opencast Tin Mining area & 50,76 & 2,46 & 155,78 & 7,56 \\
\hline Oil Palm Hardwood Plantation & 165,45 & 8,03 & 458,70 & 22,28 \\
\hline Shrubs & 122,01 & 5,95 & 61,96 & 3,01 \\
\hline Herbs and Grass & 110,52 & 5,37 & 93,04 & 4,51 \\
\hline Water Body & 36,49 & 1,77 & 13,21 & 0,64 \\
\hline Other Cultivation Plants & 14,05 & 0,68 & 113,32 & 5,50 \\
\hline Total Extend & $\mathbf{2 . 0 5 9 , 1 7}$ & 100 & $2.059,17$ & 100 \\
\hline
\end{tabular}

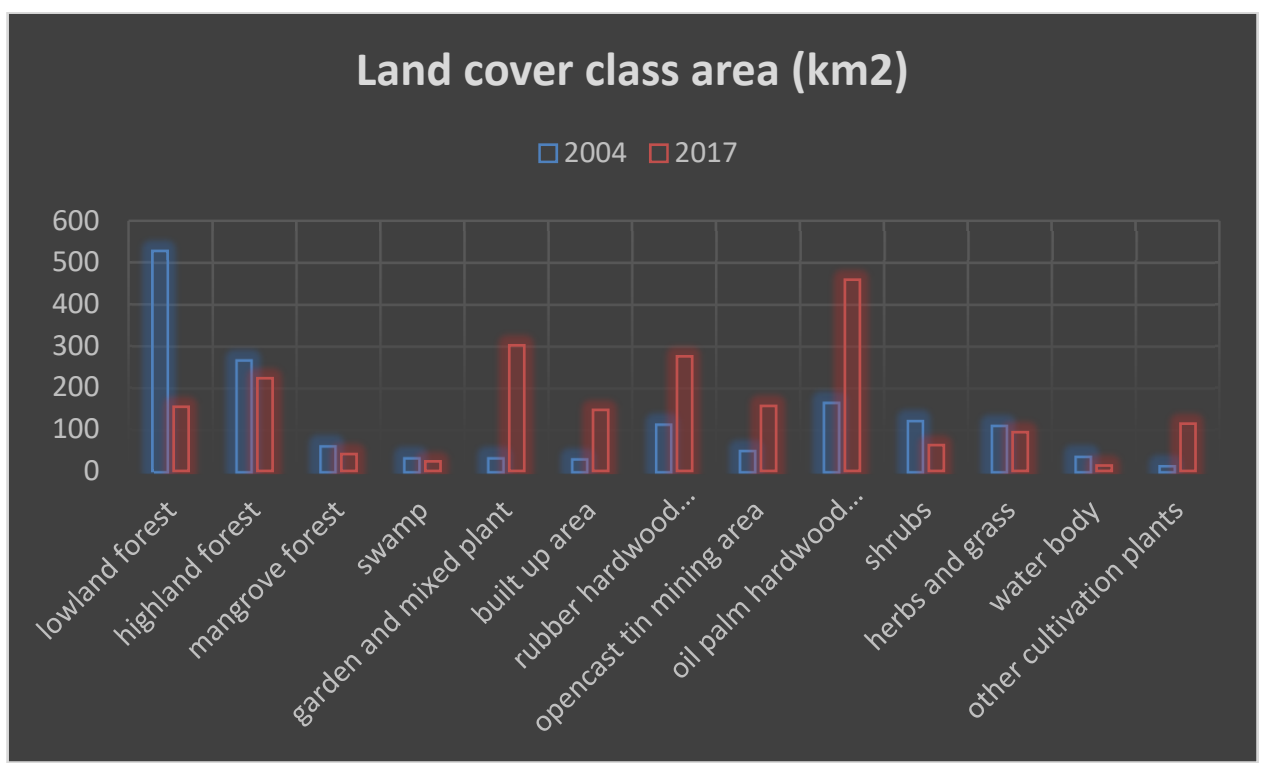

Figure 8. Land cover areas of each classes in the year 2004 and 2017 
The spatial distribution of land cover class in year 2004 and 2017 is shown by the picture below;

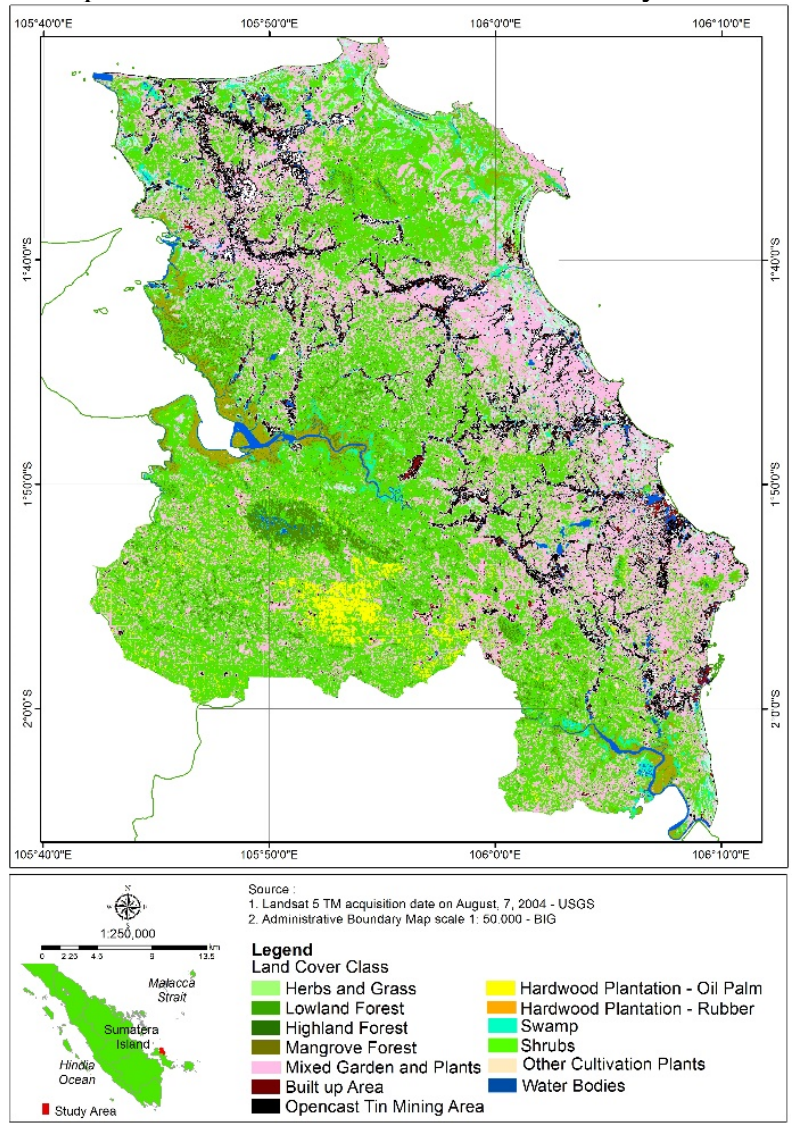

Figure 9. Land cover map of Bangka Regency (2004)

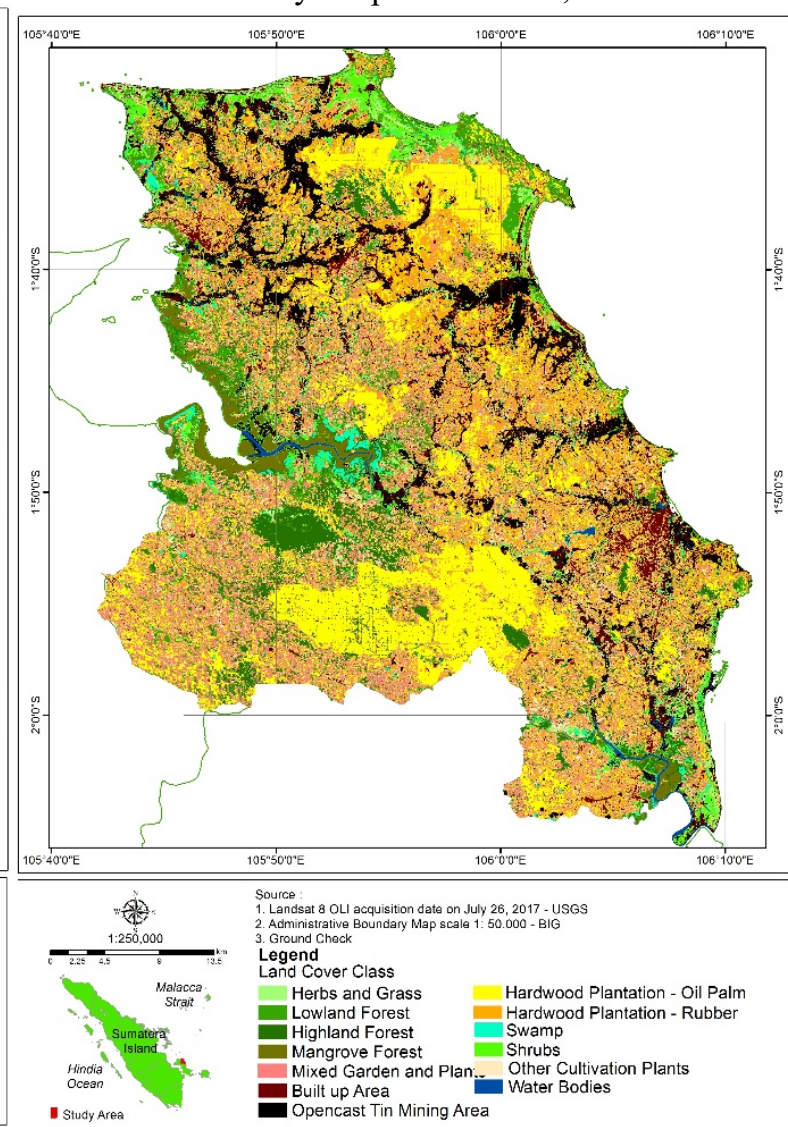

Figure 10. Land cover map of Bangka Regency (2017)

The total area of vegetated land cover in 2004 was $1.908,5 \mathrm{~km}^{2}$ while in 2017 it was reduced to $1.720,43 \mathrm{~km}^{2}$. It means that within a period of 13 years there was a decrease in the area of vegetation covering an area of $188,07 \mathrm{~km} 2$ which was converted into an opencast mining area and built up area. Of this amount, the area of vegetated land cover which has changed into mining area is equal to $64,91 \mathrm{~km} 2$ and this is equivalent to $34,53 \%$ of the total conversion area to cover land that is not vegetated. While the tin mining area in the period of 2004 to 2017 has increased by $105,02 \mathrm{~km} 2$. This means that $93.1 \%$ of the addition of this area is the result of the conversion of vegetated land cover. Information of vegetated land cover changes in the period 2004 to 2017 is presented in the table 2 and 2 then figure 6 below:

Table 2. Changes of vegetated land cover become mining areas from 2004 to 2017

\begin{tabular}{|l|c|c|}
\hline \multirow{2}{*}{\multicolumn{1}{c|}{ Vegetated Land Cover }} & \multicolumn{2}{c|}{ the Extent of Change to Tin Mining Area } \\
\cline { 2 - 3 } & $\mathbf{k m}^{\mathbf{2}}$ & $\mathbf{\%}$ \\
\hline Lowland forest & 30,15 & 46,45 \\
\hline Highland forest & 0,40 & 0,61 \\
\hline Mangrove forest & 2,08 & 3,21 \\
\hline Gardens and mixed plants & 13,81 & 21,28 \\
\hline Oil Palm Hardwood Plantation & 0,08 & 0,12 \\
\hline Shrubs & 13,36 & 20,58 \\
\hline Rubber Hardwood Plantation & 1,86 & 2,87 \\
\hline Other Cultivation Plants & 1,16 & 1,79 \\
\hline Herbs and Grass & 1,988 & 3,06 \\
\hline Total extend & $\mathbf{6 4 , 9 1}$ & $\mathbf{1 0 0}$ \\
\hline
\end{tabular}




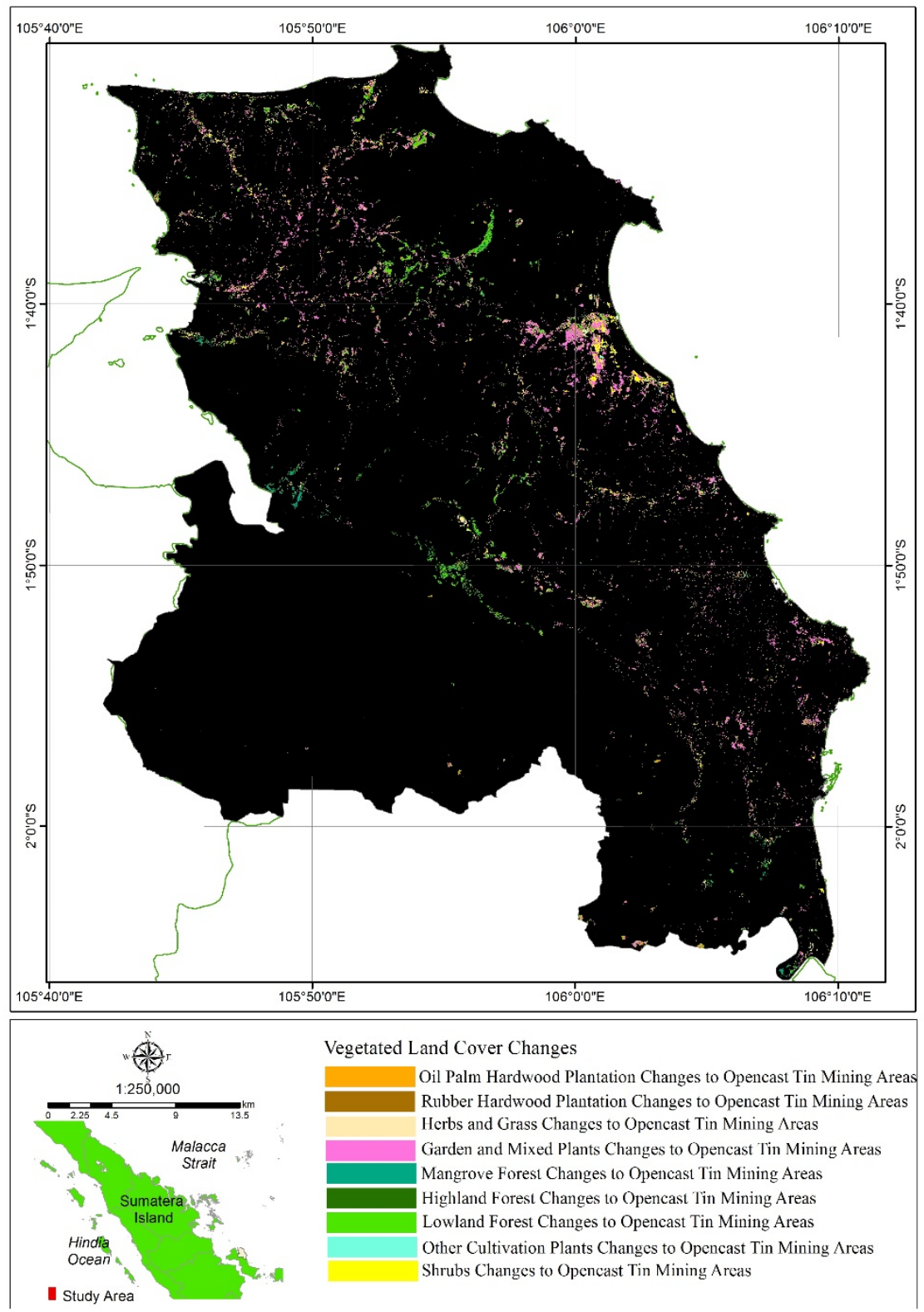

Figure 11. Map of Vegetated Land Cover Change to Opencast Tin Mining Areas

From the table show that the largest area of vegetated land cover class has been changes to opencast tin mining areas is lowland forest $\left(30,15 \mathrm{~km}^{2}\right.$ or equal to $\left.46,45 \%\right)$ and the smallest is highland forest. The picture above show the spatial distribution of vegetated land cover changes to opencast tin mining areas. North and East Bangka regency is the area that has the most vegetated land cover changes because there are several of operational mining by PT. Timah Tbk and its joint company. Mining areas whose production has been stopped by the company in terms of the effectiveness of operational costs are mostly taken over by the community in the form of illegal mining and even have destroyed a lot of forests. While in the south and west region the changes in vegetation land cover are dominated by oil palm plantations. 


\subsection{Accuracy of Classification Results}

Accuracy assessment of digital interpretation classification of land cover is done by using a matrix error ${ }^{[15]}$ where the classification reference data is collecting from ground survey. The overall accuracy value produced is equal to $84,67 \%$ with a kappa index of 0.8463 . These accuracy test results have not met the criteria as determined by the USGS ${ }^{[16]}>85 \%$. While the kappa index value above shows that $84 \%$ accuracy does not occur by chance alone. The assessment of user's accuracy and producer's accuracy are shown on the table 3 below;

Table 3. Producer's accuracy and User's accuracy Assessment

\begin{tabular}{|l|c|c|}
\hline Land Cover Class & Producer's accuracy (\%) & User's accuracy (\%) \\
\hline Highland Forest & 78,78 & 89,65 \\
\hline Lowland Forest & 83,02 & 81,48 \\
\hline Garden and Mixed Plants & 82,26 & 87,93 \\
\hline Herbs and Grass & 76,92 & 85,17 \\
\hline Shrubs & 79,03 & 75,38 \\
\hline Built up Areas & 85,39 & 90,47 \\
\hline Opencast Tin Mining Areas & 91,04 & 90,37 \\
\hline Mangrove Forest & 83,78 & 85,87 \\
\hline Rubber Hardwood Plantation & 78,26 & 83,72 \\
\hline Oil Palm Hardwood Plantation & 83,67 & 71,92 \\
\hline Other Cultivation Plants & 86,05 & 82,22 \\
\hline Swamp & 84,90 & 71,42 \\
\hline Water Body & 91,7 & 92,95 \\
\hline
\end{tabular}

From the table 3 it can be seen that the highest producer's accuracy for the 13 land cover classes in the multispectral classification process the maximum likelihood is $91,7 \%$, that is water body land cover class while the lowest accuracy is $76,92 \%$ from herbs and grass land cover class. Meanwhile, in terms of user accuracy, the highest value of $92.95 \%$ is shown by water body land cover class while the lowest accuracy is $71,42 \%$ which is the swamp land cover class. Moreover, the measure of producer's accuracy associated with the correct number of pixels. While user's accuracy reflects the reliability of the classification to the user. As a whole there is no significant difference between user accuracy and producer accuracy in each land cover class

\section{CONCLUSIONS}

This research shows that tin mining activities in some areas of Bangka Regency in the period 2004 to 2017 developed quite massively and were under control to transfer land that had previously been vegetated to open land for mining. The lowland forest, garden and mixed plants and shrubs are the land cover classes that changes as significantly to opencast tin mining areas. The expansion of mining activities into forest areas that shown in this research which is lowland forest id dominantly changes into opencast tin mining areas requires a firm policy from the local government given the main function of the land cover especially in its role in capturing pollutants in the air as a form of mitigation to climate change. Moreover, keep in mind that the rate of vegetated land cover reclamation especially hardwood forests is not proportional to the rate of damage caused by tin mining activities.

In general, this research has produced accuracy that approaches the minimum acceptance limit criteria according to USGS. Some of the shortcomings in this study that influence classification accuracy are image recording data for classification 
with reference data, there are time differences so that it is possible to change land cover into another class that is not following the results of the interpretation. Furthermore, the selection of training areas that are less homogeneous causes open land for mining to be classified into another land cover class such as built up areas. Besides that, related to the remaining tin mining or underwater filled areas, some are classified as water bodies in general which affect the data on the tin mining area itself.

\section{REFERENCES}

[1] Gardiner, N. J., Sykes, J. P., Trench, A. \& Robb, L. J.,"Tin mining in Myanmar : Production and Potential," Resources Policy 46, 219-233 (2015).

[2] Catur, U., Susanto, Yudhatama, D. \& Mukhoriyah.,"Identifikasi Lahan Tambang Timah Menggunakan Metode Klasifikasi Terbimbing Maximum Likelihood Pada Citra Landsat 8." Maj. Globe 17, 9-15 (2015).

[3] Simatupang, M. \& Sigit, S.,[Pengantar Pertambangan Indonesia. (Pusat Dokumentasi dan Informasi Ilmiah - LIPI, (1992).

[4] Mukhoriyah \& Yudhatama, D.,"Identifikasi Bekas Lahan Tambang Timah Menggunakan Citra Satelit Penginderaan Jauh ( Studi Kasus : Kabupaten Bangka Barat )," Pros. Pertem. Ilm. Tah. XX 897-903 (2015).

[5] Omotehinse, A. O. \& Ako, B. D., "The Environmental Implications of the Exploration and Exploitation of Solid Minerals in Nigeria with a special focus on Tin in Jos and Coal in Enugu," J. Sustain. Min. 18, 18-24 (2019).

[6] Yunianto, B., "Kajian Problema Pertambangan Timah di Propinsi Kepulauan Bangka Belitung Sebagai Masukan Kebijakan Pertimahan Nasional," Teknol. Miner. dan Batubara 5, 97-113 (2009).

[7] Vasuki, Y. et al., "The Spatial-Temporal Patterns of Land Cover Changes Due to Mining Activities in the Darling Range, Western Australia : A Visual Analytics Approach," Ore Geology Reviews 108, $23-32$ (2019).

[8] Danoedoro, P. [Land-Use Information From the Satellite Imagery: Versatility and Contents for Local Physical Planning]. Lambert Academy Publishing, (2009).

[9] Yunito, M. R., "Kajian Perubahan Penggunaan Lahan Akibat Penambangan Timah Berdasarkan Analisis Neraca Sumber Daya Lahan Spasial Di Kabupaten Bangka," Jurnal Bumi Indonesia 5, (2014).

[10] Jensen, J. R., [Introductory Digital Image Processing A Remote Sensing Perspective], Pearson Education, Inc, (2016).

[11] Wardani, D. W., Danoedoro, P. \& Susilo, B., "Kajian Perubahan Penggunaan Lahan Berbasis Citra Penginderaan Jauh Resolusi Menengah dengan Metode Multilayer Perceptron dan Markov Chain," MGI 30, 9-18 (2016).

[12] Huang, D. et al., "Accuracy Assessment Model For Classification Result of Remote Sensing Image Based on Spatial Sampling," Journal Application Remote Sensing. 11, 1-13 (2017).

[13] Danoedoro, P., "Pengaruh Jumlah dan Metode Pengambilan Sampel Penguji Terhadap Tingkat Akurasi Klasifikasi Citra Digital Penginderaan Jauh," Simposium Nasional Sains Geoinformasi ke-4 1, (2016).

[14] Rwanga, S. S. \& Ndambuki, J. M., "Accuracy Assessment of Land Use / Land Cover Classification Using Remote Sensing and GIS," International Journal of Geosciences 2017, 611-622 (2017).

[15] Lillesand, T. M., Kiefer, R. W. \& Chipman, J. W., [Remote Sensing And Image Interpretation], John Wiley \& Sons, Inc, (2015).

[16] Anderson, J. R., Hardy, E. E., Roach, J. T. \& Witmer, R. E. A., [Land Use and Land Cover Classification System for Use with Remote Sensor Data], United States Government Printing Office, (1976). 